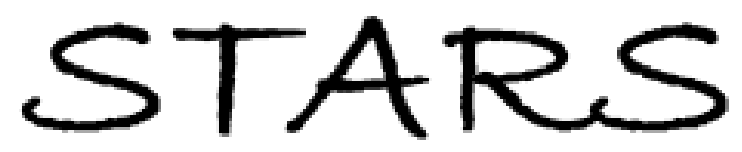

University of Central Florida

STARS

Faculty Scholarship and Creative Works

$12-2016$

\title{
Latour's AIME, Indigenous Critique, and Ontological Turns in a Mexican Psychiatric Hospital: Approaching Registers of Visibility in Three Conceptual Turns
}

\author{
Beatriz M. Reyes-Foster \\ University of Central Florida, beatriz.reyes-foster@ucf.edu
}

Part of the Social and Cultural Anthropology Commons

Find similar works at: https://stars.library.ucf.edu/ucfscholar

University of Central Florida Libraries http://library.ucf.edu

This Paper is brought to you for free and open access by STARS. It has been accepted for inclusion in Faculty Scholarship and Creative Works by an authorized administrator of STARS. For more information, please contact STARS@ucf.edu.

\section{Original Citation}

Reyes-Foster, Beatriz. 2016. "Latour's AIME, Indigenous Critique, and Ontological Turns in a Mexican Psychiatric Hospital: Approaching Registers of Visibility in Three Conceptual Turns" Anthropological Quarterly 89(4): 1175-1200.

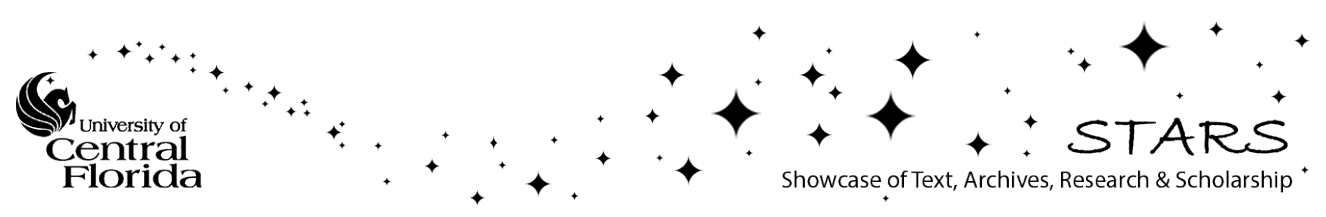




\title{
Latour's AIME, Indigenous Critique, and Ontological Turns in a Mexican Psychiatric Hospital: Approaching Registers of Visibility in Three Conceptual Turns
}

\author{
Beatriz M. Reyes-Foster
}

Published in Anthropological Quarterly Winter 2016 Issue.

Reyes-Foster, Beatriz. 2016. "Latour's AIME, Indigenous Critique, and Ontological Turns in a Mexican Psychiatric Hospital: Approaching Registers of Visibility in Three Conceptual Turns" Anthropological Quarterly 89(4): 1175-1200. 


\begin{abstract}
The "ontological turn" presents an opportunity to re-examine anthropological engagements with various phenomena across multiple modes of existence. One possible terrain for engagement is the acute ward of a psychiatric hospital in Yucatan, Mexico, where psychiatrists, patients, and various invisible beings coexist. By examining the actions and words of patients and doctors in the ward, I consider Latour's engagement with invisible beings in his recent publication, AIME, alongside critiques from indigenous scholars who argue that scholarship in the ontological turn ignores indigenous frames of reference that already grant ontological status to nonhumans. I engage in an ontological reading of the concept of (in)visibility in the writing of indigenous scholars to explore how indigenous ontologies can inform my analysis. Finally, I build on my engagement with Latour and indigenous critique to introduce the concept of registers of visibility as a mode of existence that encompasses both what an actor is capable of seeing and how an actor renders themselves visible to others.
\end{abstract}

Key Words: Indigenous scholarship, (in)visibility, ontology, Latour, modes of existence, psychiatry, Mexico. 


\section{Introduction}

It is mid-July 2012 in a large city in the southeastern state of Yucatan, Mexico. The heat is sweltering; the rainy season has just started, and with the rains have come the mosquitoes. At Las Lomas ${ }^{1}$ the new psychiatry interns, from other, less humid, parts of Mexico, often think that the patients suffer from skin allergies or rashes, because of the severity of the mosquito bites which blanket the patients' arms, legs, backs, and faces. The lack of mosquito netting on the ward windows and the broken fans only exacerbate the problem. For the patients who are tied to their beds, unable to swat away the persistent insects, the only thing standing between them and a bout of dengue fever is luck. The heat and mosquitoes are the least of their problems: conditions inside this public psychiatric facility have been described as horrific in the local press and online forums. This is no hospital, some have argued, but little more than a medieval dungeon.

Efrain, a 31 year old Maya man from a rural community several hours away from Las Lomas, had spent four days locked inside the psychiatric ICU when I first met him. When we spoke, he explained that he had been brought to Las Lomas because he had been possessed by a demon. Although his wife and child had beaten the intruding presence out of his body, his mother had decided to take him to the hospital to care for his injuries. When he was assessed at the local clinic, he was referred to Las Lomas and transported to the city by ambulance. When our interview ended, one of the attending psychiatrists asked how the interview had gone.

"It went well," I said, noncommittally. 
She raised her eyebrows in a bemused expression, "he's still psychotic, right?"

Was Efrain "still psychotic"? His doctors concluded stress in his marriage and work life resulted in a severe depression with accompanying psychotic symptoms. They reached that conclusion because Efrain claimed to have been possessed by the devil and because he claimed he could converse with birds (more importantly, that the birds spoke back). However, Efrain assured me he was not mentally ill at the same time he explained he had been possessed and his birds had spoken to him. What if we granted Efrain's devil and talking birds ontological status, if we accepted their real-ness? In other words, is it theoretically productive to take his claims "seriously"?

Recent years have seen a burgeoning interest in the so-called "ontological turn" in anthropology (Descola 2013; Latour 2007; 2013; Viveiros de Castro 2014; Mol 2003). Within this growing body of literature, Latour's most recent book, An Inquiry into Modes of Existence: An Anthropology of the Moderns (2013), AIME, attempts to go beyond his most recent iteration of Actor-Network theory, the framework he outlines in Reassembling the Social. AIME is the result of 25 years of inquiry, presenting a framework for understanding "the Moderns" that examines not only the connections between various networks and domains, but also the coexistence of various modes of existence.

A key feature of AIME that making particularly attractive to anthropologists working in psychiatric settings is AIME's explicit engagement with invisible beings. ${ }^{2}$ AIME considers invisible beings, with their ability to transform those whom they affect, to exist in their own mode of existence, [MET], for metamorphosis. This move 
forces us to break away from traditional western dualisms: subject/object, health/illness, real/unreal towards a theory that sees reality as the complex interaction of multiple modes of existence present across and between domains ("Science," “Law," "Religion," and so on).

AIME is called "an anthropology of the Moderns," yet who a "Modern" is admittedly vague. Mexico is certainly "Modern," yet it is also postcolonial. More importantly, power, hierarchy and inequality are dramatically real inside the wards of Las Lomas. AIME can easily seem too idealistic, to function too smoothly in its empirical application, to be applicable in a decidedly dysfunctional context. Moreover, indigenous scholars have made the troubling accusation that the socalled ontological turn's interest in the agency of nonhuman actors replicates preexisting indigenous ontological frameworks without engaging them. ${ }^{3}$

In this article, I consider the possibilities of an AIME-informed analysis of Las Lomas and present a critique of the realities of repression experienced by the patients in its wards. In the wake of the ontological turn in anthropology, critiques from indigenous anthropologists and other indigenous scholars about the (in)visibility of indigenous thought in Academia are useful in understanding the connections between invisible beings and invisible people. In this article, I use "three conceptual turns" as a device to illustrate this usefulness in the ethnographic context of a public psychiatric hospital in in Yucatan, Mexico. I introduce a new possibility for understanding the experiences of acute patients confined to a psychiatric ward, complementing rather than replicating other analyses based on the theorization of experience, subjectivity and biopower in psychiatric 
anthropology (Biehl 2005; Brodwin 2013; Desjarlais 1997; Farmer 2004; Good 1994; Jenkins and Barrett 2004; Luhrmann 2001).

I introduce the notion of registers of visibility as a conceptual tool for understanding both an ontological pluralism taking invisible beings seriously while accounting for the reality of unequal modes of existence. I do this in three conceptual moves: first, I provide an AIME-inspired Latourian analysis of the psychiatric ward and the invisible beings residing there. Second, I describe the treatment of psychiatric patients as a process of invisibilization bearing strong parallels to the invisibilization of indigenous people by the Mexican State and of indigenous thought in Euro-American academic writing. The second move is a deliberate attempt to decolonize my analysis by including an engagement with indigenous metaphysics and ontology. Finally, this engagement brings me to propose that the visible and invisible actors of Las Lomas exist in registers of visibility encompassing both what actors are capable of seeing and how they are visible to others.

\section{The Research Setting}

Las Lomas is a 160-bed public facility. It provided inpatient and outpatient psychiatric and psychological services to 69,000 people in 2011 . The acute ward, the primary setting of the research informing this manuscript, is an intensive care ward inside Las Lomas. There are approximately 24 beds evenly divided into male and female dormitories, though all beds are almost never filled. The wards are not air conditioned, and many of the fans supposed to bring the heat down were broken in the summer of 2012. 
The people who use this facility are among the poorest in the region: many of them are Yucatec Mayan speakers (though the hospital does not keep track of how many Mayan speakers and ethnic Mayas are committed each year) from rural communities with poor access to mental health care services and medication. By the time they are committed to Las Lomas, patients are generally in a state of escalating for some time. By the time they arrive, patients have likely already visited a traditional healer and made use of local low-cost health care clinics. Some of Las Lomas's clientele comes from the Instituto Mexicano del Seguro Social (IMSS) or the Instituto de Seguridad Social para los Trabajadores del Estado (ISSSTE), organizations providing health services to public and private employees. However, the case loads of these physicians, who essentially "rent out" hospital space, are much smaller than those with Seguro Popular, the government low-cost insurance option for those outside the IMSS and ISSSTE systems, or no insurance.

Inside the facility's intensive care unit conditions are especially difficult: Patients must wear a uniform, are allowed no personal property, including books or reading material, and sleep in a long dormitory at the end of which, in the open, are toilets and showers, always visible to the nursing staff. The toilets often break, and repairs are slow to come, creating a nearly unbearable stench in the entire dormitory. Patients are locked down in this dormitory for 18 to 20 hours a day, only allowed out into the ward lobby to eat their meals and, if they have visitors, to sit at tables with them between 10 am and 12 noon. Failure to comply with hospital rules can result in the application of physical restraints or isolation. 
The extreme order imposed upon patients is in tension with a chaos created by circumstances affecting the proper functioning of the institution itself: preferred medications are often unavailable; the Electro Convulsive Therapy (ECT) machine frequently breaks down; the hospital runs out of supplies such as drug tests and doesn't replace them (making it difficult to rule out psychiatric symptoms that could be drug-induced and hindering diagnosis); facilities are not properly maintained; precautionary measures are not taken and patients contract mosquito-borne diseases; turf wars between nurses and physicians spill over into patient care. This chaos presents a sharp contrast -and a notable obstacle-to the institution's mandate to order the bodies of its patients.

I spent three months conducting participant observation research inside Las Lomas, where I rotated through the acute ward, the psychiatric emergency room, and psychiatric outpatient treatment. I concentrated the majority of my time inside the acute ward, where I established a good working relationship with the attending physicians and patients. I interviewed 24 psychiatric patients committed to the acute ward and all three attending psychiatrists. I also directly witnessed the treatment of about 50 others inside the acute ward and about 30 patients using the hospital's urgent care and outpatient services. In addition to one-on-one interviews, my months of immersion inside the hospital allowed me close interaction with 10 psychiatry and integrative medicine residents: five inside the acute ward, three in the psychiatric emergency room, and two in outpatient service. I attended a psychiatry class for medical students and a case analysis meeting. I also conducted two semi-structured interviews with psychiatrists working outside of Las Lomas. 
In my semistructured interviews with patients, we discussed their understanding of health and illness and perceptions of care providers and condition. I asked patients to describe a "healthy" versus an "unhealthy" person. I asked them whether they believed they were sick. My semistructured interviews with doctors focused on how they spent their time inside and outside of Las Lomas, their responsibilities inside Las Lomas, how their private practice differed from their hospital practice, and the greatest obstacles they faced in their work. Finally, I also asked them to give me their definition of a healthy person.

The data yielded by my ethnographic engagement with patients and doctors at Las Lomas is at the heart of the theoretical intervention this paper is attempting. More than a simple backdrop against which I develop the idea of registers of visibility through an engagement with Latour's AIME and the work of indigenous scholars, the ethnographic conditions themselves challenged my theoretical analysis and pushed me to think beyond those tools immediately available to me in the work of the theorists I was reading. In this sense, my conceptual framework is firmly grounded in ethnography.

\section{First Turn: Approaching Latour's AIME and Invisible Beings}

In AIME, Latour guides the reader through a comprehensive theory for sorting through human practices. He identifies various modes of existence: law [LAW], political autonomy [POL], religion [REL], and so forth. The [PRE] mode, for pre-position, refers to position-taking before a position is stated. The [REF] mode, for chains of reference -perhaps as close as we can get to epistemology (83). Relevant to this article, Latour also introduces his own definition of a category 
mistake; in contrast to mistakes of the senses, category mistakes are mistakes "of direction," requiring a change of "interpretive key" -a key attached to each mode of existence allowing the researcher to recognize it. Interpretive keys allow the researcher to avoid making the mistake squared, the modern mistake of assuming that objective knowledge is the only way to judge truth and falsity (58).

By Chapter 7 of AIME, Latour, having demonstrated that the idea of the "visible world" is the result of a category mistake, and uncovered the pluralism of modes of existence (178), turns his attention to what he calls the "beings of metamorphosis" (181), the invisible beings modernity has relegated to the "irrationality" of other cultures and explained as products of the individual psyche. For Latour, the Moderns' need to deny the existence of these forces and explain them through what he regards as the questionable prism of psychology points to the very ability these forces have to act upon human beings. Where in other cultures, these beings are managed through ritual, the Moderns are quick to deride the "superstitions"; at the same time, they are affected/afflicted by them in the form of mental illness. The Moderns need to situate these forces inside the mind and thus deny their existence. Yet, as much as they may try to deny the existence of these forces or explain them as "internal," the fact remains they continue to deeply affect them. The effect of these forces on the continuity of the Modern self is so powerful it manifests as a mode of existence [MET]:

The continuity of a self is not ensured by its authentic and, as it were, native core, but by its capacity to let itself be carried along, carried away, by forces capable at every moment of shattering it or, on the contrary, of installing themselves in it. Experience tells us that these forces are external, while the official account asserts that they are not only internal -no, that they are nothing. Nothing happens. It's all in our 
heads. One thing is certain: we have here a form of continuity that is obtained by leaps, by passes, by hiatuses through a dizzying discontinuity (196).

The [MET] mode refers to the ways invisible beings transform themselves and transform those around them. They do not exist in the same way tables and chairs exist, but they nevertheless have ontological status (199). AIME introduces 15 modes of existence, all of which can interact with one another in encounters Latour refers to a "crossings." Thus, after recognizing the existence of invisibile beings in the [MET] mode, Latour's protagonist dismisses the centrality of matter (and materialism) as a category mistake.

As a Modern space, the staff at the psychiatric hospital interprets patient engagement with invisible beings as symptoms that are, as Latour describes, internal to the patient. When Dr. Castro describes how he measures improvement in his patients, he begins with looking to see that the patient no longer recognizes the existence of the invisible beings around him:

[I look for] a reduction in the consistency of the delirium, that the patient sleep well, that he eat well, that he cooperate and respond when he is interviewed. The interview with the family is really important as well, and it is also important to remember that improvement is relative, that there are people who are not going to be "well" the way the family wants them to be... [Field Recording].

However, the passage above also reveals that, even as psychiatric symptoms are considered internal to the patient, the way improvement is assessed is largely through observations of the patients' external behavior: that the patient sleep, eat, and otherwise cooperate. Thus, in this psychiatric encounter we begin to see a breakdown in the very distinction of internality and externality. This allows the patient the opportunity to modify her behavior without denying the existence of the 
"delusion." At times, patients are even able to negotiate which "delusion" they want to keep:

Pacheco: $\quad$ Manuela, are you bothered by the fact that sometimes I, that I might doubt some of the things you tell me? I feel that not everything you tell me is true. There are many things that are true, but there are others that are not. Do you mind that sometimes I do not believe everything you tell me?

Manuela: $\quad$ Do you think I am a liar?

Pacheco: $\quad$ No. Well, it is not that you are a liar-

Manuela: $\quad$ I understand. When I tell you things about myself, you do not believe it all, just about half?

Pacheco: $\quad$ More or less half. Exactly. I believe part of it. But when you tell me you completed five degrees, it seems difficult. I mean, not impossible, butManuela: $\quad$ Okay, let me keep just one. I studied-

Pacheco: $\quad$ haha, yes, I like that, that's right.

Manuela: $\quad$ I studied to be a handcraft teacher.

Pacheco: $\quad$ Okay, that's more like it. It's more believable. (Field recording)

This exchange illustrates a sort of negotiation taking place between Manuela

and Dr. Pacheco. By pointing out the unlikeliness of Manuela's claim to have completed five degrees, Dr. Pacheco got Manuela to compromise and "keep" one of the five. What is unclear in the exchange is first, whether Manuela believes she only completed one degree, and second, whether it matters. What is clear is that it pleases Dr. Pacheco for Manuela to make more "believable" claims about her life. In this back-and-forth, Manuela understands her ability to leave Las Lomas depends on Dr. Pacheco's opinion of her progress.

Manuela was found wandering the streets in a city over five hours away from Las Lomas. She had no identification, and was unable to tell her name to the police officers who found her. She was committed as a Jane Doe to Las Lomas, where she remained, unable to communicate and confined to a solitary observation room, for nearly a month. Manuela spent most of that month screaming incoherently, spitting 
at doctors and nurses, or tied to her bed, sedated. Without any way of verifying her identity, there was no family to contact. Without drug testing strips, at first there was no way of knowing if her behavior was drug induced. One Monday, about a month after she first arrived, I came in to the hospital to discover that Manuela had become responsive over the weekend. She was able to tell Las Lomas staff her name, and her family was finally contacted.

However, some things about her story did not seem quite right. Manuela claimed to hold five degrees, to be employed by Interpol, and to speak French, English, and Mayan. She said she was a citizen of Canada and resided in Montreal. After she finally revealed her name, and hospital workers contacted her family, Las Lomas staff learned she had been living in Cancun and working in a grocery store. She apparently been struggling with depression for years; according to them, this was not the first time she lost touch with reality. Her family believed her delusions were triggered by the death of her only child eight years prior. She went missing for several months before she was found in a different city several hours away.

When I interviewed her, Manuela insisted she had never lost her sense of reality:

Manuela: $\quad$ I have never lost my sanity, even though they have drugged me. Reyes-Foster: You have always been completely aware of everything going on around you?

Manuela: $\quad Y e s$, I was coherent. I remember when they brought me in. And I am still coherent, no matter what they do. (Field recording)

If Latour grants ontological status to invisible beings, why not grant ontological status to the world that Manuela inhabits? Rather than constructing it as delusion or alternative reality, we can use Latour's framework to imagine Manuela's 
world as part of the same world inhabited by those who do not recognize its existence, overlaid like a transparent film, transforming Manuela from a grieving mother to an Interpol agent.

Likewise, Efrain, the patient described above, did not believe he was suffering from a mental illness. Efrain lived in a small village in rural Yucatan. He worked as a small-scale farmer and a tricycle taxi driver, but a difficult agricultural year had prompted his wife to take on a job at a local maquiladora, an exportprocessing factory. This caused conflict in the marriage, and Efrain began to believe his wife was unfaithful. Soon after the conflicts began, Efrain began experiencing frightening visions. He began to hear animals, particularly his pet cardinal birds, speaking to him. A strict Pentecostal, he became convinced that he was the subject of a demonic possession.

It was, it was... everything was all mixed up there and... in the night, I tell my wife, when I woke up, I tell her, "hey, let's... or help me pray." And when she heard that I was speaking in tongues like that and I was praying, she said, you are not my husband, she said. "Why not?" I asked. "Because you are not my husband. You are the evil spirit who is inside you," she said. "Why do you say that?" I said, and we went outside, to the kitchen. "you are the evil spirit," she said. "How can it be?" I said. "Yes, you are the evil spirit." "How can you prove it?" "This is how I prove it." And she hit me, my wife, she hit me here, but, really, really hard. And said to her "hit me so that the evil spirit that you say is inside me will leave." Then she said, "son, come here," she said to my 12-year-old son, "son, come see your dad, come see your dad. He is not your dad," she said, "where is he? He says, "look, see how he's grabbed my hair," and she says, "hit him." And so my son hits me and that's how I got this black eye."

He ran into the woods after his son hit him, and spent the night in them.

When he came home the next day, he found his house empty, save for his pet cardinal birds. The mated pair had a chick, and Efrain began conversing with them. He took the birds to his parents' home. 
So I arrived at my mom's. I arrived at my mom's and I say, "mommy.." [and she says] "why is your face like that? Who hit you?" she says. And I said "Well, my wife and my son." "How can that be?"

"Yes."

"Why, then?"

And my little sister, [she says] "oh, brother, what is happening to you is not normal," she says. "Why? Why are you talking to the birds?"

She could hear me talking to them, and I said, the baby, the baby folds his wings, both of them... he folds them like this... so they want to fly. And he turned like this... he turned back and started to say that they are going to fly, to fly. You fly, he said, and do not tell them it is me, said the baby. And I, what could I do? I started to talk with my dad, but he couldn't understand me. And with my sister, but she couldn't understand me. And... well...

My little sister says, brother, I am very sorry, she says, but I am going to set your cardinals free.

"Why?"

"I'm going to set them free, brother. Poor birds, would you like to be locked up the way they are locked up?" She says.

"No," I say.

"So let them go, let them go and let them live like we live," she says.

With tears, with tears and pain, I let them go. But so you see, they didn't go far. They stayed near the house and started to sing and sing, all three of them. Yes. Then my wife left, and they started to find a van so they could bring me here.... [the birds] come from God, because I fed them, but I had them locked in a cage, and it is not right to keep them locked up. Just like I'm locked up, right? I am fed, but I do not have freedom.

As a Maya man and a Pentecostal Christian, his worldview already included the existence of the devil and the reality of demonic possession. It granted birds the ability to speak. An approach informed by Latour's AIME takes the demonic seriously, allowing us to understand how Efrain, contrary to his doctor's belief, could be possessed by the devil or speak to animals (or claim this was the case) without being psychotic.

So far, in this first conceptual turn, I applied Latour's framework to my own ethnographic setting, and found it is a fruitful way of re-conceptualizing what I previously thought of as the patients' internal worlds. By granting ontological status 
to the invisible beings and invisible facts inhabiting the acute ward and interacting with its patients in transformative ways, the framework places patients and care providers on conceptually equal footing, as well as the birds, demons, clothing, medications, the ECT machine, and other actors inhabiting the acute ward.

However, patients and care providers are most certainly not on equal footing. In postcolonial Yucatan, the complexity of encounters happening on the ground stretches the boundaries of Latour's easy prose: yes, modern psychiatry attempts to deny the existence of external forces. Yes, these forces have ontological status. Yes, Maya psychiatric patients already grant these forces ontological status. So what? These forces continue to exist in a setting plagued by the realities of political economy, corruption, and human rights violations. I find myself troubled by the ease with which the AIME project can be applied and by its limits. Kim Fortun's (2014) critique of the AIME project comes to mind as she considers the project's contribution in the context of late industrial disasters: "The political economic is mostly absent, as is the discursive... the way history weights the present and the future, at all scales and in all systems, is discounted [in AIME]" (315). Yet in my particular research setting, the weight of political economy and history cannot be denied.

AIME may accommodate both political economy and history through its use of crossings and various modes of existence - the [MET*PRE] or [MET*REF] crossings might be useful for thinking through the existence of invisible beings in their postcolonial subtext and context. The possibilities of the [MET] mode are certainly promising, but, the application of a [MET*PRE] feels forced: indeed, a 
search using AIME's online interface for this crossing came up empty, despite the many contributors to the AIME platform. [MET*REF] yields limited results. While Latour suggests it is possible to use the beings of [MET] to analyze positive knowledge in psychiatry, these questions steer away from my own observations in the oppressive space of the psychiatric ward. Fortun (2014) argues there is a conceptual "diplomacy" implicit in AIME that underestimates the "toxicity" of the vitalism of late industrialization - thus, while the AIME framework cannot deny the harm to humans that comes from industrial chemicals, it simply does not address it. While Fortun speaks of environmental disasters, the same argument can be made of the "soiled grounds" that is the psychiatric ward: the framework does not meaningfully address the suffering or harm to human beings inside the ward. Although AIME supplied a productive analytical tool that allowed me to engage with the concept of invisible beings -and (in)visibility itself-through the [MET] mode of existence, I found this analysis could be enhanced by bringing it into conversation with an anthropology of -or, more accurately, by-indigenous people, who have long been grappling with and writing about (in)visiblity.

\section{Second Turn: Indigenous Critiques and the Materiality of Invisibility}

The question of (in)visibility -alongside that of intelligibility—is at the heart of much writing in the field of indigenous studies in the Americas. In Latin America, indigenous identity has taken on unique form and complexity in the wake of nationalistic projects like indigenismo and mestizaje that highlighting certain aspects of indigenous identity and render others invisible (de la Cadena 1996, Lomnitz 2001, Castellanos, Gutiérrez Nájera, and Aldama 2012). Thus, in Mexico, the banner 
of indigenismo (Gamio 2010(1916)) was the centerpiece of post-revolutionary Mexican nationalism. Indigenismo may have intended to value Mexican indigenous knowledge and life ways, but it gave way to logics of mestizaje that celebrated a homogenous Mexican "cosmic race" resulting from "the best" attributes of its Spaniard and Indigenous parentage (Vasconcelos 1997(1925)). Mestizaje thus resulted in the devaluing and invisibilization of indigenous people who did not "fit" the nationalistic narrative (de la Cadena 2000).

The Maya identity of Yucatan has long been a topic of conversation and analysis among scholars of the region (Hervik 1999, Castañeda 2004, Castillo Cocom 2005, Breglia 2006, Author 2012). Yucatec Maya anthropologist Juan Castillo Cocom (2005) argues that the Yucatecan state has manufactured an essentialized version of "the Maya" as an object of tourist consumption, rendering the "real" indigenous of people of Yucatan, who are more likely to identify by their political party affiliation than they are as "Maya," invisible.

In an interesting parallel, the so-called ontological turn has recently generated critique from indigenous scholars. In a blog post that went viral in 2014, indigenous feminist Zoe Todd notes that despite commonalities between indigenous worldviews that perceive the agency and sentience of nonhuman actors, indigenous scholars who have worked using similar frameworks for decades have been routinely ignored in academic writing outside of indigenous studies. Similarly, Kim TallBear notes, "I am struck over and over reading the new materialisms ${ }^{4}$ by the lack of acknowledging indigenous people" (2016: 17). For TallBear and Todd, this 
scholarly silencing of indigenous thought simultaneously embraces a theoretical framework replicating its fundamental metaphysics.

The ideas of visibility and invisibility raise a series of questions: what does invisibility mean? Who is the "viewer" to which things are visible or invisible? And why is (in)visibility relevant to the ontological analysis of the psychiatric ward? Is thinking about invisibilization as a process undergone by (and done to) people theoretically productive in a Latourian modes-of-existence analysis? The possibility that indigenous people can inhabit multiple modes of existence by manipulating their visibility could be gleaned from the work of indigenous scholars writing in the field of Native Studies (Cook-Lynn 1998; Smith 2014; Smith 1999; Bowen 2012; Rains 1999) who have, not surprisingly, written extensively about In(Visibility). Andrea Smith's $(2013,2014)$ concept of ethnographic entrapment and Audra Simpson's (2007) call for ethnographic refusal present an opportunity to think through the (in)visibility of indigenous people in academia and beyond. Smith builds on the work of Denise da Silva, Rey Chow, and María Josefina Saldaña-Portillo to argue that Native peoples in academia are in a double bind: they must prove the "worthiness" of indigenous peoples as "human" by making themselves known and knowable, but in the act of doing this they become part of a colonialist machinery because what determines the worthiness is the white gaze. For instance, Chow (2014) notes ethnic studies scholars are pressured to live up to the ethnographic niche to which they have been assigned while at the same time disavowing a representational stance. ${ }^{5}$ 
One way out, writes Audra Simpson $(2007,2014)$, is through ethnographic refusal, a basic ethnographic calculus of "what you need to know and what I refuse to write in" (72). In other words, ethnographic refusal, the practice of leaving things unsaid in ethnographic writing (therefore, rendering what remains unsaid invisible) is an opportunity for indigenous people to escape ethnographic entrapment. However, when indigenous scholars, in act of deliberate ethnographic refusal, purposefully obscure or exclude certain knowledge from their writing that is considered part and parcel of quality ethnographic writing (Simpson 2007), their standing as scholars suffers because what constitutes academic writing is determined by white logics. Thus, Smith recognizes that indigenous scholars can render their work intelligible or unintelligible to Western academia in so far as they make the knowledge about indigenous people they possess visible or invisible. This results in a paradox: visibility or intelligibility comes at the price of colonization. Visibility cannot liberate.

Clearly, in the examples above, the invisibility of indigenous people is discursive, not ontological: indigenous people are invisible because they are absent in state narratives, formation processes, and programs. Through ethnographic refusal, they may render themselves visible or invisible in academic writing about them. This process, which can be understood as one of invisibilization, is one indigenous people are both subjected to (as argued by Castillo Cocom), and which they enact for themselves (as argued by Audra Simpson). In these analyses, the gaze that determines visibility is inherently colonial and colonizing. However, when Latour writes about invisible beings, these do not exist in a supposed contrast with a 
visible world, but in fact inhabit a different mode or template for existence (2013: 202). Ontology is a metaphysics with a material, rather than discursive, locus. Invisible beings are real because they literally transform their targets.

However, metaphysics are not new to indigenous thought. For example, Vine Deloria Jr. (2001) writes about the potential contributions of an indigenous metaphysics to the broader social and natural sciences. Pointing out the disastrous effects of persistent western ignorance of indigenous knowledge about the natural world, Deloria proposes that if metaphysics is understood "as simply that set of first principles we must possess in order to make sense of the world... Indian knowledge of the natural world, of the human world, and of whatever realities exist beyond our senses has a consistency that far surpasses anything devised by Western civilization" (3). While some may argue against Deloria's claim regarding the consistency of indigenous knowledge, the North American Indian metaphysics he outlines grants agency to non-human actors and invisible beings. This metaphysics, he argues, can enable indigenous scientists (and others willing to take it seriously) to arrive at a position of "suspended judgment" in interpreting scientific knowledge and findings, an expansionist -rather than reductionist-stance.

Deloria's argument is in response to a Western interest in indigenous peoples' knowledge of the natural world. Rather than focusing on this knowledge as a collection of accumulated facts, Deloria argues for focusing on the metaphysics informing how these facts were arrived at in the first place. If one accepts Deloria's claim that his proposed metaphysics is shared by most North American Indians ${ }^{6}$ one could argue that Simpson's and Smith's ideas of ethnographic refusal and 
entrapment are similarly derived from a pre-existing metaphysic. The question of the invisibility of indigenous people becomes relevant to our analysis of invisible beings in the psychiatric ward because psychiatric patients, like indigenous people, fluctuate in their invisibility: in other words, they inhabit multiple modes of existence.

These examples index a parallel between Latour's description of Western denials of invisible forces and ethnographic entrapment. The Western process of denying existence to invisible beings described by Latour certainly appears in Las Lomas, where patients themselves go through a process of invisibilization inherent in the bodily restrictions imposed on patients when they arrive. Patients are stripped of their individual personhood when they are made to wear uniforms and medicated without consent. This mechanism is not limited to the imposition of a uniform and the ministration of medications, but extends to control every aspect of a patient's external life: when he eats, when she sleeps, when he showers, when she gets out of bed. Patients experience ethnographic entrapment -they become visible and understandable only when they "fall in line". They are only recognized when they submit, and remain invisible when they do not.

For Efrain, the hospital uniform holds the power to transform him into an enfermo, much like the metaphorical power held by invisible beings in Latour's AIME.

"what I see right now, I do not like it. I feel like an enfermo [sick person], I feel... I feel that I do not... I feel sick with [the uniform]. If I could dress in my own right clothing, I would be better." [Field recording] 
Although he does not believe he is sick, he acknowledges that the very wearing of the uniform makes an enfermo. What made him feel sick was the fact that he was forced to wear the hospital uniform. Dressing in his "own right clothing" then, will restore him to health. ${ }^{7}$

While Latour's AIME allows us to think of the uniform as having the power to transform, it is the work of indigenous scholars writing from their own theoretical frameworks that best allows the reader to understand the power of the uniform to transform Efrain from a healthy person into a sick one. The importance of the hospital uniform calls attention to the materiality of nonhuman agents. While the works of New Materialisms scholars Coole and Frost (2010) and Bennett (2010) encourage us to see materials as "productive, not simply static, dead, acted upon" (TallBear 2016:10), Kim TallBear (2016) observes that the "New Materialisms" are not so new. Recalling Deloria's metaphysics in her analysis of cryopreservation of indigenous tissues, Tallbear notes that indigenous standpoints inherently recognize the vitality of things (12).

The hospital uniform thus is one of several processes of invisibilization undergone by psychiatric patients at Las Lomas. For indigenous patients, who represent the majority of the patient population, this invisibilization includes worldview, customs, and traditions. As Dr. Vásquez, a psychiatrist employed at Las Lomas who also holds a degree in anthropology, pointed out, the drive to coerce patients into complying with institutional standards of eating and sleeping does not take into account the lived experience -what he referred to as "cultural background" — of many of Las Lomas's patients. 
Think about it, many of our patients do not sleep in beds, they sleep in hammocks. Yet we expect them to sleep comfortably in this environment. They might be used to eating beans and tortillas, and using their hands when they eat. Yet we expect them to eat a set menu and to use utensils. Some of the women may never wear anything other than their huipil (traditional Maya dress) and we force them -sometimes physically-to wear the hospital uniform. And then when they resist we label them as "uncooperative" [Field notes].

This lack of "cultural" awareness, however, is not because the psychiatrists are unaware of the lifeways of indigenous people in Yucatan -all of the attending psychiatrists know Maya people sleep in hammocks and wear huipil, as does any person born and raised in Yucatan. Additionally, Dr. Castro lived in a remote Maya village as a young man, Dr. Pacheco learned Mayan from his grandparents, and Dr. Tun is ethnically Maya, though she does not speak Mayan. It is the institution that demands uniformity from its patients, seeking to eliminate differences. Attending psychiatrists, like everyone else in the institution, must comply with this demand, often against their better judgment and with some ambivalence. ${ }^{8}$

In this second conceptual turn, I have explored the concept of (in)invisibility through the lens of indigeneity. The limit to thinking about modes of existence using AIME is the stark reality that patients have bodies being violently acted upon. Deloria's Indigenous metaphysics, alongside Smith's ethnographic entrapment and Simpson's ethnographic refusal, incorporates the possibility of unequal as well as multiple modes of existence. I identified the way in which invisibilization as a mechanism of domination takes place in the context of the psychiatric ward.

This second turn complicates the initial analysis of invisible beings enabled by AIME. In what way does granting ontological status to invisible beings matter in a place like the acute ward? One could argue that in the ugly reality of the psychiatric 
hospital, Latour's AIME seems like a self-indulgent escape into circular conversations about ontological plurality and metamorphic invisible beings. By the same token, however, an ontology informed by an indigenous metaphysic may allow us to apprehend processes of transformation and invisibilization in the ward in a new way: it is not that invisible beings exist in a separate dimension contrasted to a visible world, but that they exist differently. I would argue the same mechanism holds true inside Las Lomas: the personhood of psychiatric patients committed to the acute ward is rendered invisible by the regimentation of the ward.

\section{Third Turn: Approaching Registers of Visibility}

It may be productive to return to Latour here. In Latourean analysis, all actors have ontological status. However, it is misleading to state that any of these actors -doctors, patients, medicines, demons, birds, ECT machines—has ontological status without accounting for how they are differentially subjected to violence in acts of invisibilization, or through systems rendering them invisible. One possible "way out" is to think about actors existing in registers of visibility. I borrow the concept of register from linguistics. A linguistic register is "a repertoire that is associated, culture-internally, with particular social practices and with persons who engage in such practices..." (Agha 2004:24, emphasis in original). Thus, someone may dominate various registers which may or may not be mutually understandable -they are said to possess a register range. In the same way actors have a linguistic register range, being able to speak in specific contextually driven ways, we can conceptualize actors as possessing a range of registers of visibility. Registers of visibility encompass both what an actor is capable of seeing and how an actor is 
visible to others. In this sense, one productive way of thinking about invisible beings may be to compare the coexistence of beings to the coexistence of linguistic registers: mutually unintelligible languages coexist on the same planet, yet the degree to which a person fluent in one register may encounter another and hear gibberish or hold a conversation depends on the person's command of that register. Some people only command one register of a particular language, others are polyglots.

Moreover, this shifting of registers -code-switching, to borrow another term from linguistics-is compatible with the [MET] mode: according to Latour, invisible beings exist in the [MET] mode because they have the ability to transform those they interact with. Since inside the acute ward the patients closely coexist with invisible beings while the psychiatrists decidedly ignore them, it is the patients who are transformed by their invisible beings, and in this transformation become capable to code-switching between multiple registers of visibility. Their polyglottality is the result of their passing through the [MET] mode.

Thus, when we speak of registers of visibility, we can say psychiatric patients are often polyglots -they can see multiple registers and have a limited ability to manipulate their own visibility. This was evident in my interviews, when patients like Manuela, described above-would indicate they clearly understood where they where and why without sacrificing the ontological status of what the psychiatrists considered delusions. Manuela could perceive both registers of visibility. By manipulating the claims she made about who she was, her personhood shifted in its 
register and became more recognizable to Dr. Pacheco because he saw the behavior he imagined to be agentive.

Efrain, the man who was afflicted with a demonic possession, was keenly aware of what he had to do to be released.

X: $\quad$ And do you believe that you are sick?

E: $\quad$ No, of course not.

X: $\quad$ All right, so tell me, what is a sick person like?

E: $\quad$ A sick person, doesn't think things correctly. Sometimes he says one thing, or he cries for any little thing, or... he cannot walk, he's sick. He's sad all the time, he's a sick person, he feels like that... like an ogre, like that, angry, is an angry person. Yes.

$X: \quad$ So what is a healthy person like?

E: $\quad$ A healthy person is... dresses well, grooms himself, chats... he says pretty words... he talks to everyone, he shares his feelings. That is why I always speak pleasantly to the doctors and the nurses. So they see I am healthy, and not sick like my mother thinks [Field recording].

Efrain considered himself healthy. He was free of the demon who had possessed him thanks to his wife and son's intervention. He never sacrificed the reality of the demon, or the reality of the talking birds. It was the uniform, as he said before, that was making him sick. However, he knew he had to render himself understandable to make himself visible - to the doctors and nurses. To do this, he stopped speaking of birds and demons and instead focused on showing his care providers how healthy he was. His tactic paid off: he was released from the acute ward the day of our interview.

Likewise, patients use their ease with these registers of visibility for other reasons. Angelica was a young woman suffering from an eating disorder. In the three-month period I spent at the acute ward, Angelica was in and out of Las Lomas four times. With each commitment, Angelica's symptoms seemed to morph: she 
entered the hospital with an eating disorder diagnosis. Three subsequent suicide attempts brought her back to the acute ward, and each time she heard she was about to be released she would claim she was suicidal again. The fourth time she was committed, she told hospital employees she regularly heard voices and had been "seeing two children" for years.

Angelica tried to manipulate people she saw as having positions of authority by repeating what she believed was a discourse that guaranteed she would stay committed, a discourse she adapted from other patients she interacted with during her stay. She admitted as much to me in an interview:

See, I'm smart. I know what to say to get what I want. I didn't want help before, that's why I never said anything about the children before. But now I'm ready to get help (Field notes).

Without sacrificing the reality of the children she claims to see (does she really see them? Does it matter?), Angelica, like Efrain, recognizes her ability to choose how she behaves in order to get specific results. At the same time, she says she wants help -what is unclear is first, how she defines help (help to remain inside the acute ward and avoid whatever it is she wants to avoid on the outside?) and second, whether she actually wants help or whether the statement itself is part of her strategy.

While still claiming to hallucinate (a claim everyone around her doubted), Angelica indicated an understanding of the institution. Certain claims and behaviors -suicidality, auditory and visual hallucinations, temper tantrums-triggered specific procedures. Angelica knew a suicide attempt would get her committed, that claiming to be suicidal would keep her inside the acute ward, and that claiming to 
hear and see things would result in increased attention from hospital doctors, nurses, and staff regardless of whether or not staff believed any of these claims were real. In what her attending psychiatrist, Dr. Tun, saw as a manipulative cycle, Angelica would "behave herself" when she became tired of being committed and "misbehave" when she wanted to return.

Is Angelica visible or invisible? Although Dr. Tun might say that Angelica is vying for attention -therefore seeking visibility-her desire for the hospital's tactics of invisibilization -the uniform, the medication, the restraints-indicate that what she is craving is actually invisibility, or invisibility in one particular register. Angelica embraces her invisible beings because they transform her [MET], they grant her fluency in the register of visibility.

\section{Discussion}

Indigenous standpoints are at the front edge of the ontological turn; they merit greater engagement in anthropological writing. As Kim TallBear meditates on the exclusion of indigenous thought from the new materialism, she ponders:

Indigenous people, our movements and our voices are the others ${ }^{9} . .$. The invisibility of our ontologies, the very few references to them in their writing, and reference to indigenous thought by other theoretical traditions as "beliefs" or artifacts of a waning time to be studied, but not interacted with as truths about a living world-is to deny our vibrancy (17).

Engaging indigenous ontologies in studying mechanisms of oppression is more than a political statement; it is methodologically and theoretically sound. This article could not have arrived at its conclusion without relying on these frameworks to think through the ethnographic material. 
This article arrived at the concept of registers of visibility through three conceptual turns. First, by applying Latour's most recent work, AIME, to the case study of a psychiatric hospital in southern Mexico, I considered the ramifications of granting invisible beings and invisible realities ontological status. However, in doing this I found eschewing the question of hierarchy and domination altogether rather difficult given the mechanisms of oppression I witnessed in the ward. Second, after identifying (in)visibility as a key concept moving forward in my analysis, I then engaged with writing of indigenous intellectuals from both North and Latin America using the lens of (in)visibility to analyze the representation and construction of indigenous people and indigenous identities in academia and beyond. Specifically, I used TallBear and Deloria's writing on indigenous ontologies to analyze the invisible beings in the psychiatric ward. Finally, I built on this analysis by introducing the idea of registers of visibility. I argued that a useful way to incorporate the reality of the processes of (in)visibility described above is through the idea of registers of visibility by which patients, transformed by their interactions with invisible beings, are able to render themselves visible or invisible in their interactions with psychiatric staff.

An ontological reading of ethnographic refusal is closely tied to the idea of registers of visibility. These concepts are relevant to thinking through many different ethnographic contexts beyond the one described in this article. In the context of the ontological turn, the potential of indigenous ontologies and theoretical frameworks to understanding the vibrancy of the visible and invisible 
beings around is more important than ever. Registers of visibility may be one of productively engaging in this endeavor.

\section{Acknowledgements}

The author would like to thank Elizabeth Farfán-Santos and Gabriela Ríos for their critical readings of earlier versions of this piece and the anonymous reviewers who provided thoughtful feedback on the original submission of this manuscript. Kim Tallbear shared her unpublished book chapter, "Beyond the Life/Not Life Binary: A Feminist-Indigenous Reading of Cryopreservation, Interspecies Thinking and the New Materialisms" with me during the writing of this manuscript. Her intervention directly influenced the development of this article's argument. I thank her for her generosity. This research was made possible with funding from the University of Central Florida department of Anthropology.

\section{Notes}

1. This research was conducted with approval from the UCF Institutional Review Board (protocol ID SBE-12-08337) for the protection of human subjects. The approved protocol was granted exempt status by the UCF IRB with the following provisions: 1) no identifiable information was collected, the name and exact location of Las Lomas have been changed to disguise its identity; all names are pseudonyms to protect the identities of research participants, 2) all patients who participated in interviews had to be cleared by their attending psychiatrist prior to the interview to ensure they were capable of making informed consent. I carried out a consent procedure with each participant, explaining the purpose of the research, what to 
expect in our interview, and that patients had the ability to decline or withdraw from the study at any time. 27 patients were cleared for interviews by their physicians. Two patients indicated they did not wish to participate in the interview during the consent process. Las Lomas did not require any additional human subjects review.

2. Latour describes AIME as a different project from ANT. In AIME's website, which was conceived as an integral part of the project, Latour writes "since the two projects have been running in parallel for over twenty-five years... we have also maintained a kind of 'software compatibility' between the projects... it is just that within the aime project, the whole of the ant approach becomes but one mode among many (it is called [net] for 'networks')" (Latour 2013).

3. The "ontological turn" in anthropology goes far beyond Latour's writing (Descola 2013; Viveiros de Castro 2014, Mol 2003). Interestingly enough, Viveiros de Castro's (2014) Cannibal Metaphysics is an indigenous metaphysics proposing precisely the idea that indigenous philosophies can and should be taken "seriously," not just as a tool for understanding indigenous thought, but as a way of expanding and furthering the field of philosophy itself. Viveiros de Castro uses Deleuzian immanence to render these metaphysics intelligible to European scholarship, but falls short of engaging with the work of Amerindian scholars such as Vine Deloria Jr (2001) and Kim Tallbear (2016) also writing about indigenous metaphysics. Unfortunately a full engagement with Viveiros de Castro and other potentially productive scholars of the ontological turn such as Annemarie Mol is beyond the scope of this piece, and will be addressed in a future publication). Moreover, AIME is 
certainly not Latour's only or most influential publication (Latour 1993; 2004; 2007; 2010), and one could argue -as Peter Skafish (2014) does in his English translation of Cannibal Metaphysics - that Latour should be considered separately from other works in the so-called ontological turn. Due to the fact that AIME is a complex undertaking, I found it more productive to engage deeply with one particular work and bring it into conversation with the work of indigenous scholars than to attempt to engage superficially with his larger and rather prolific body of work.

4. A branch of ontology that seeks to understand the agency of nonhumans as coconstitutive of human lives.

5. Smith (2014) notes that ethnographic entrapment is not exclusive to indigenous people, but to any people who assume that liberation happens by making themselves known. These people are then faced with having to articulate who they are and what their struggle is in ways that are understandable to those who do not face their struggles.

6. This, of course, requires a significant leap, for although scholars like Deloria, Tallbear, Smith and Simpson may present indigenous metaphysics/philosophy/worldview as consistent and unified, many anthropologist might balk at this characterization, perhaps going so far as to accuse it of being overly simplistic and of erasing the complexity of indigenous identity in North America and beyond. Indeed, I have written on the complexity of Maya identity (Reyes-Foster, 2012) in Yucatan, for instance, and am aware of some of the problematics of accepting Deloria's claim at face value. It is true that all of these authors write themselves in opposition to a dominating colonial structure, 
replicating what may be to many anthropologists a worn-out "us vs. them" binary opposition that has long outlived its usefulness. I would argue that if indigenous scholars like Kim Tallbear $(2013,2016)$, a brilliant anthropologist who has published influential work widely read in Science and Technology Studies, continue to note the salience of this opposition vis à vis the overlooking of the work of indigenous scholars in anthropological theory, then perhaps this is because the opposition remains salient. Scholars in Native Studies like Denise Ferreira da Silva (2007) go so far as to argue that Euroamerican scholarship is inherently colonialist and cannot exist without a non-European "other." I would ask the reader to momentarily set this resistance aside to allow the argument of this piece to follow course.

7. The hospital uniform, of course, is also an actor -Jane Bennett (2010) would refer to the uniform's ability to transform Efrain as its "thing-power," and perhaps place it among other "vibrant" materials with transformative powers in the ICU (medications, needles, the ECT machine, the strips of cloth used for binding, the nonworking toilets and fans).

8. All three of the attending psychiatrists identified contradictions between their own beliefs about best practices and hospital policy, yet they, too, complied with the institutional mandates despite their misgivings. In AIME, Latour identifies contradictions as two variations to take into account in understanding the gap between theory and practice in society: values and fluctuations (45). Values are the primary means by which a mode of existence is known -they define specific domains (faith in Religion, means in Law, proofs in Science). By the same token, 
values are not static of homogenous, but are always changing and interfering with each other. Thus, we can understand the acute ward's psychiatrists as navigating different domains (the State, the Institution, Psychiatry) and fluctuating values (compliance, order, treatment). This analysis is outside the scope of this article and will warrant exploration in a future publication.

9. TallBear is referencing the 2001 film The Others. 


\section{References Cited}

Agha, Asif

2004 Registers of Language. In A Companion to Linguistic Anthropology. A.

Duranti, ed. Pp. 23-45. Oxford: Blackwell.

Bennett, Jane

2010 Vibrant Matter: A Political Ecology of Things. London and Durham: Duke University Press.

Biehl, João

2005 Vita: Life in a Zone of Social Abandonment. Berkeley: University of California Press.

Bowen, Deirdre

2012 Visibly Invisible: The Burden of Race and Gender for Female Students of Color Striving for an Academic Career in the Sciences. In Presumed Incompetent: The Intersections of Race and Class for Women in Academia. G. Gutiérez y Muhs, Y. Flores Niemann, C.G. González, and A.P. Harris, eds. Boulder, CO: University of Colorado Press.

Breglia, Lisa

2006 Monumental Ambivalence: The Politics of Heritage. Austin: University of Texas Press.

Brodwin, Paul

2013 Everyday Ethics: Voices from the Front Line of Community Psychiatry. Berkeley: University of California Press.

Castellanos, M. Bianet, Lourdes Gutiérrez Nájera, and Arturo Aldama, eds. 
2012 Comparative Indigeneities of the Americas. Tucson: University of Arizona Press.

Castillo Cocom, Juan

2005 'It Was Simply Their Word': Yucatec Maya PRInces in YucaPAN and the Politics of Respect. Critique of Anthropology 25(2):131-155.

Castañeda, Quetzil

2004 "We are not indigenous!" An Introduction to the Maya Identity of Yucatan. The Journal of Latin American and Caribbean Anthropology 9(1):36-63.

Chow, Rey

2014 Not Like a Native Speaker: On Languaging as a Postcolonial Experience. New York: Columbia University Press.

Cook-Lynn, Elizabeth

1998 American Indian Intellectualism and the New Indian Story. In Natives and Academics: Researching and Writing About American Indians. D. Mihesua, ed. Lincoln: University of Nebraska Press.

Coole, Diana, and Samatha Frost, eds.

2010 New Materialisms: Ontology, Agency, and Politics. Durham and London: Duke University Press.

da Silva, Denise Ferreira 2007 Toward a Global Idea of Race. Minneapolis: University of Minnesota Press. de la Cadena, Marisol 
1996 The Political Tensions of Representations and Misrepresentations: Intellectuals and Mestizas in Cuzco (1919-1990). Journal of Latin American Anthropology 2(1): 112-147.

Deloria Jr., Vine

2001 American Indian Metaphysicis. Power and Place: Indian Education in America. V. Deloria Jr. and D. Wildcat, eds. Pp. 1-6. Golden, CO: Fulcrum Publishing. Descola, Philippe

2013 Beyond nature and culture. J. Lloyd, transl: Chicago ; London : The University of Chicago Press, 2013.

Desjarlais, Robert

1997 Shelter Blues: Sanity and Selfhood Among the Homeless. Philadelphia: University of Pennsylvania Press.

Farmer, Paul

2004 Pathologies of Power: Health, Human Rights, and the New War on the Poor. Berkeley: University of California Press.

Fortun, Kim 2014 From Latour to Late Industrialism. Hau Journal of Ethnographic Theory 4(1): 309-329.

Gamio, Manuel 2010(1916) Forjando Patria: Pro-Nacionalismo (Forging a Nation). Fernando Armstrong-Fumero (trans). Boulder: University Press of Colorado. Good, Byron 
1994 Medicine, Rationality, and Experience: An Anthropological Perspective. Cambridge: Cambridge University Press.

Hervik, Peter

1999 Mayan People Within and Beyond Boundaries: Social Categories and Lived Identity in Yucatán. Amsterdam: Hardwood Academic Publishers.

Jenkins, Janice Hunter, and Robert John Barrett

2004 Schizophrenia, Culture, and Subjectivity: The Edge of Experience. Cambridge: Cambridge University Press.

Latour, Bruno

1993 We have Never been Modern. C. Porter, transl. Cambridge: Harvard University Press.

2004 Why has Critique Run out of Steam? Critical Inquiry 30(2):225-248.

2007 Reassembling the Social: An Introduction to Actor-Network Theory. Oxford: Oxford University Press.

2010 On the Modern Cult of the Factish Gods. Durham: Duke University Press. 2013 An Inquiry into Modes of Existence: An Anthropology of the Moderns: Harvard University Press.

Lomnitz, Claudio

2001 Deep Mexico, Silent Mexico: An Anthropology of Nationalism. Minneapolis: University of Minnesota Press.

Luhrmann, Tanya

2001 Of Two Minds: An Anthropologist Looks at American Psychiatry. New York: Vintage. 
Mol, Annemarie

2003 The Body Multiple: Ontology in Medical Practice. Durham: Duke University Press.

Rains, Frances V.

1999 Dancing on the sharp edge of the sword: Women faculty of color in white academe. Everyday Knowledge and Uncommon Truths: Women of the Academy. L.K. Christian-Smith and K.S. Kellor, eds. Boulder, CO: Westview Press.

Simpson, Audra

2007 On Ethnographic Refusal: Indigeneity, 'Voice' and Colonial Citizenship. Junctures: The Journal for Thematic Dialogue 9:67-80.

2014 Mohawk Interruptus. Durham: Duke University Press.

Skafish, Peter

2014 Introduction. Viveiros de Castro, Eduardo. Cannibal Metaphysics: For a PostStructural Anthropology. Peter Skafish (trans.). Minneapolis: Univocal.

Smith, Andrea

2014 Native Studies at the Horizon of Death: Theorizing Ethnographic Entrapment and Settler Self-Reflexivity. In Theorizing Native Studies. A. Smith and A. Simpson, eds. Durham and London: Duke University Press.

Smith, Linda Tuhiwai

1999 Decolonizing Methodologies: Research and Indigenous Peoples. London: Zed Books.

TallBear, Kim 
2013 Native American DNA: Tribal Belonging and the False Promise of Genetic Science. Minneapolis: University of Minnesota Press.

2016 Beyond the Life/Not Life Binary: A Feminist-Indigenous Reading of Cryopreservation, Interspecies Thinking and the New Materialisms. In Cryopolitics: Frozen Life in a Melting World. J. Radin and E. Kowal, eds. Cambridge, MIT Press (In Press).

Todd, Zoe

2014 An Indigenous Feminist's take on the Ontological Turn: 'ontology' is just another word for colonialism. In Urbane Adventurer: Amiskwacî, Vol. 2015: Wordpress.com.

Vasconcelos, José

1997(1925) The Cosmic Race/La raza cósmica. Didier Jaén (trans). Baltimore: The Johns Hopkins University Press.

Viveiros de Castro, Eduardo

2014 Cannibal Metaphysics: for a Post-structural Anthropology. Peter Skafish (trans.). Minneapolis: Univocal. 